\title{
ELOGIO DEL ReINO. RAFAEL GAMBRA Y LA REIVINDICACIÓN DEL TRADICIONALISMO POLÍTICO
}

[In praise of the Kingdom.

Rafael Gambra and the claim of political traditionalism]

\author{
Julio Alvear Téllez*
}

\begin{abstract}
RESUMEN
En este artículo se analiza la formulación del pensamiento político antimoderno realizada por Rafael Gambra, en continuidad con el tradicionalismo político hispano de los siglos XIX y XX. La noción de "Reino" sirve al autor para asentar una evaluación negativa de la modernidad política, que condensa en el racionalismo y su configuración dominante: el Estado "racional". En dicho contexto, resaltamos la crítica al liberalismo, como teoría y sistema, momento central de la desintegración política. En contraposición, la "monarquía social y representativa” emerge como modelo histórico e idea regulativa, equivalente a una realización adecuada de aquello que los clásicos denominaban ciudad o comunidad política.
\end{abstract}

\begin{abstract}
This article discusses the reformulation of the monarchical thought made by Rafael Gambra, in continuity with the political traditionalism of the 19th and 20th centuries. The notion of "Kingdom" helps the author to settle a negative evaluation of political modernity, which condenses in rationalism and its dominant configuration: the "rational" State. In this context, we underline the critique of liberalism, as a theory and political system, the central moment of the political disintegration. In contrast, the "monarchy social and representative" emerges as a historical model which is equivalent to a proper realization of what is known as the classic city or political community.
\end{abstract}

RECiBIDO el 18 de mayo de 2016 y APROBADO el 7 de junio de 2017

* Profesor de filosofía política y jurídica de la Universidad del Desarrollo. Dirección postal: Facultad de Derecho, Universidad del Desarrollo, Av. La Plaza 680, Santiago, Chile. Correo electrónico: jalveart@udd.cl 
Palabras ClaVES

Reino, monarquía social y representativa, comunidad, exilio, racionalismo, Estado racional, liberalismo
KEY WORDS

Kingdom, social and representative monarchy, community, exile, rationalism, rational State, liberalism.

\section{INTRODUCCIÓN}

En los estudios sobre el pensamiento político la monarquía, aparece, por definición, como el gobierno de uno ${ }^{1}$. Esta visión cuantitativa fundada en tipos ideales, no da cuenta, sin embargo, del fenómeno del "Reino", nombre de régimen más que de gobierno, presidido por un príncipe, titular de un poder limitado intrínseca y extrínsecamente, al que se aproximaron cualificándolo diversos filósofos políticos de la neo-escolástica, como Vitoria ${ }^{2}$, Suárez ${ }^{3}$, Mariana ${ }^{4}$ o Quevedo .

1 Son clásicos los textos de la monarquía como "gobierno de uno" y sus beneficios "morfológicos" en relación con el principio de unidad y de continuidad. TOMÁs DE Aquino, De regno ad regem Cypri (Toronto, The Pontifical Institute of Mediaeval Studies, 1949), I, 3.

${ }^{2}$ Para Vitoria, el poder real es una potestad civil, sujeta a las exigencias de su fin y a la legalidad que le precede, sea de carácter divino, natural o consuetudinario. El rey es ministro de Dios, no de la República. Vitoria, Francisco, De la Potestad Civil, en El Mismo, Relecciones Teológicas. El Estado y la Iglesia (Madrid, Publicaciones Españolas, 1960) 7, 8, 11 y 21.

${ }^{3}$ Suárez concibe el principado del rey a modo de principio unitivo y expresivo de la comunidad política. Y ésta, en cuanto "cuerpo místico", se funda en un consenso moral voluntario, histórico y providencial, resultante de una conjunción de causas naturales, humanas, temporales y divinas. SuÁrEZ, Francisco, Defensio Fidei (Madrid, CSIC, 1965), III Principatus politicus, n. 2, 5; 3, 4. Es notable cómo el jurista granadino descarta la soberanía (supremus dominus, supremus simpliciter) como nota del poder real cristiano. SuÁrEz, Francisco, Defensio Fidei (Madrid, CSIC, 1978) IV Iuramento Fidelitatis Regis Angliae, n. 2, 2. Al respecto, Alvear, Julio, Francisco Suárez y los límites del poder político, en SÁnCHEZ, Pablo (Dir.), Historia del análisis político (Madrid, Tecnos, 2011), pp. 267-277.

${ }^{4}$ Mariana considera la "potestad real" como "el mejor de todos los poderes". Pero se trata de un poder temporal supremo, no soberano; "protector de la multitud, presidido por uno". Un poder en todo cualificado: hereditario; sujeto a las leyes y costumbres del reino; prudente y justo; representativo, consentido y aconsejado. Mariana, Juan de, Del Rey y de la institución de la dignidad real (traducción de E. Barriobero, Buenos Aires, Partenon, 1954), pp. 33 y 45-62.

5 Para Quevedo el poder real es un poder civil de carácter tutelar (“a vuestro cuidado, que no a vuestro albedrío, encomendó las gentes Dios nuestro Señor”), ministerial, protector (“Reinar es velar. Quien duerme no reina”), aconsejado, justicie- 
En la misma línea, los pensadores hispanos de los siglos XIX y XX, convencionalmente calificados como "tradicionalistas", cualificaron el poder del Rey, atribuyéndole funciones políticas específicas y sujetándole a límites jurídicos y morales que hacen incompatible, al menos en principio, la idea de Reino con la concepción moderna del Estado soberano, sea democrático o autocrático.

En este punto, el aporte del tradicionalismo político es relevante, pero insuficientemente conocido. En España se le definió erróneamente como "absolutista" en circunstancias que desde sus orígenes, desde la época de Fernando VII, evidencia lo opuesto ${ }^{6}$.

La limitación y cualificación del poder del Rey es connotada por casi todos los pensadores políticos de esta corriente, como, por ejemplo, Donoso Cortés ${ }^{7}$, Aparisi ${ }^{8}$, Vázquez de Mella ${ }^{9}$, Del Burgo ${ }^{10}$ o Polo ${ }^{11}$, para centrarnos en el ámbito español.

ro, ejemplar y pacífico. Quevedo, Francisco de, Política de Dios, Gobierno de Cristo, en El Mismo, Escritos Políticos (Madrid, Editora nacional, 1956), pp. 7, 77-82, 27, 44-45, 60-61.

${ }^{6}$ Puede considerarse "el manifiesto de los persas", suscrito del 12 de abril de 1814, como la primera condensación ideológico-política del tradicionalismo hispano. Dirigido contra el liberalismo estatista y regalista triunfante en la Constitución de Cádiz, reivindica ante Fernando VII la vuelta del antiguo régimen, no del absolutismo. La diferencia es clave y fue resaltada en su época por Federico Suárez. WILHelmsen, Alexandra, El Manifiesto de los Persas: una alternativa al liberalismo español, en Revista de Estudios Políticos 12 (1979) pp. 141-172.

${ }^{7}$ El poder monárquico se subordina más perfectamente a la ley universal de la "unidad y de la variedad". Es un poder que mejor garantiza la unidad, la perpetuidad y la limitación. Donoso Cortés, Juan, Carta al director de Revue de Deux Mondes, en El Mismo, Obras (Madrid, Imprenta de Tejado, 1855), V, pp. 211-234.

${ }^{8}$ El poder real es un poder sagrado, de alianza tácita con el pueblo, garante de la constitución histórica, de las libertades personales concretas (por oposición al liberalismo doctrinario), de los cuerpos autónomos y del pluralismo social (por oposición al centralismo y la uniformización estatal). La libertad es antigua, el despotismo moderno. Aparisi y Guijarro, Antonio, El Rey de España (Madrid, Tip. Ramón Ramierz, 1869), pp. 16, 22-24, 31-34. Una ácida crítica al liberalismo y al juego artificial de las constituciones escritas en cit. pp. 36-39.

${ }^{9} \mathrm{El}$ poder real ha de ser personal, tradicional, hereditario, federal y representativo. Vazquez Mella, Juan, Textos de doctrina política (Estudio preliminar, selección y notas de Rafael Gambra, Madrid, Publicaciones Españolas, 1953), pp. 107-141.

${ }^{10}$ El poder real es templado y limitado: debe respetar y hacer respetar el derecho natural y los fueros comunales. No puede sobrepasar los buenos usos y costumbres consagrados. DEL BurGO, Jaime, Ideario (Madrid, CTC, 1979, 6a ed.) pp. 10-11.

${ }^{11}$ El poder real, por no ser soberano, admite elementos "demóticos" y "aristárquicos". El rey es tal por la gracia de Dios, en legitimidad a la sucesión dinástica y en fidelidad al patrimonio histórico-político de su pueblo. Polo, Fernando, ¿Quién 
La preocupación se encuentra incluso en Carlos VII ${ }^{12}$. En este sentido, el poder del Rey no se identifica con el poder del gobernante de un Estado monocrático. Se trata de un poder cualificado que corona la cúspide de un régimen político al que mejor cabe la denominación de "Reino" que de Monarquía ${ }^{13}$.

En su delimitación conceptual, el "Reino" es una especie dentro del género "comunidad política" de los clásicos ${ }^{14}$. Puede caracterizarse desde el ángulo de la historia ${ }^{15}$, del pensamiento político-jurídico ${ }^{16}$ y de las

es el Rey? La actual sucesión dinástica en la Monarquía Española (Sevilla, Editorial tradicionalista, 1968) p.22-25.

${ }^{12}$ El poder real es unitivo (de la patria plural), protector (de los necesitados) y templado por tradición y continuidad histórica. CARLOS VII, Carta Manifiesto al Infante don Alfonso de Borbón y Austria-Este, en FERRER, Melchor, Escritos Politicos de Carlos VII (Madrid, Editora Nacional, 1957), pp. 38-43.

${ }^{13}$ La distinción es esencial para Volkoff, Vladimir, Du Roi (Paris, Julliard / L'Âge d'Homme, 1990), pp. 5-9.

${ }^{14} \mathrm{La}$ "comunidad política" es susceptible de diversas denominaciones según el principio de unidad que quiera destacarse: polis, imperio, reino, corpus mysticum, etc. Voegelin, Eric, Hitler et les allemands (Paris, Seuil, 2003), p.66. Senellart le denomina "Régimen" para oponerlo al Estado moderno. Senellart, Michel, Les arts de gouverner. Du "Regimen" medieval au concept de gouvernement (Paris, Seuil, 1995), p.22

15 Para el tradicionalismo, el modelo histórico de la comunidad política se encuentra en los reinos de la Cristiandad medieval, y en ocasiones, con ciertas ambivalencias, en la monarquía legada por los Reyes Católicos. Los estudios sobre los reinos medievales son infinitos. Para una visión general, Dugan, Anne K. (Comp.), Kings and Kingship in Medieval Europe (London, King's College London Mediaeval Studies, 1993), pp. 12-453; Boureau, Alain et Ingerflom, Claudio Sergio, La royauté sacrée dans le monde chrétien (París, Ecole des hautes études en sciences sociales, 1992), pp. 9-161, y Le Goff, Jacques et Schmitт, Jean-Claude (comps.), Dictionnaire raisonné de l'Occident medieval (París, Fayard, 1999), pp. 985-1004 (voz "Roi"). Para Francia, Le Goff, Jacques, Saint Louis (Notre Dame, University Notre Dame Press, 2009), pp. 519-557. Para España es útil Maravall, José Antonio, El concepto de reino y los "Reinos de España" en la Edad Media, en Revista de Estudios Políticos 73 (1954), pp. 81-144; ElíAS DE TeJadA, Francisco, Las Españas. Formación histórica. Tradiciones regionales (Madrid, Ambos Mundos, 1948), pp. 39-259; ZAMORA, Patricio, Reyes y Virreyes de la monarquía hispana a la luz de las significaciones politicas del siglo XVII y de la historiografía, en Revista de Humanidades 25 (2012), pp. 191-208.

${ }^{16}$ La bibliografía es abundantísima. Como referencia, Michael OAKESHOTT, Lecciones de Historia del Pensamiento Politico (traducción de Francisco Javier López, Madrid, Unión Editorial, 2012), pp. 263-330; SEnELLART, Michel, Les arts de gouverner, cit. (n.14), pp. 15-147; Jouvenel, Bertrand de, El Poder. Historia natural de su crecimiento (Madrid, Unión Editorial, 1998), pp. 75-81, 273-290; GALVAO DE Sousa, José Pedro, La Representación Política (Madrid, Marcial Pons, 2011), pp. 103-137; Dickinson, John, The medieval conception of kingship and some of its limi- 
"ideas regulativas" ${ }^{17}$. Una de las tareas centrales del tradicionalismo político hispano durante los siglos XIX y XX ha consistido en fundamentar el "Reino" como régimen político (desde las tres perspectivas anteriores) a fin de oponerlo al Estado constitucional moderno, particularmente de signo liberal. En el epítome de aquel movimiento se encuentran las figuras de Elías de Tejada ${ }^{18}$, Alvaro D'Ors ${ }^{19}$ y Rafael Gambra ${ }^{20}$.

tations, as developed in the Policraticus of John of Salisbury, en Speculum (1926), pp. 308-337; ElíAs DE TejadA, Francisco, Historia de la literatura política en las Españas (Madrid, Real Academia de Ciencias Morales y Políticas, 1991), Vol. II, pp. 11-325 y Vol. III, pp. 55-229; OrTIZ, Marco, El concepto de rey, reino y territorio en las Siete Partidas, en Revista del Posgrado en Filosofía de la Universidad de los Andes, 23 (2012), pp. 137-164

17 Born, Lester Kruge, The perfect Prince: a study in $13^{\text {th }}$ and $14^{\text {th }}$ century ideals, en Speculum III (1928), pp. 470-504; Le Goff, Saint Louis, cit. (n.14), p.315-339 con especial atención al "Espejo de los Príncipes"; García Pelayo, Manuel, El Reino de Dios, Arquetipo Político (Madrid, Revista de Occidente, 1959), pp. 27-225; Bell, Dora, $L$ ỉdéal éthique de la royauté en France au moyen âge: d'après quelques moralistes de ce temps (Paris, Droz, 1962), pp. 9-187.

${ }^{18}$ Elías de Tejada estudia el "Reino" ("monarquía tradicional") desde la perspectiva de la historia de las instituciones político-jurídicas hispanas. Ayuso, Miguel, La filosofía jurídica y política de Francisco Elías de Tejada (Madrid, Fundación Elías de Tejada, 1994), pp. 287-349. Las dos obras más representativas en la materia son Elías DE TEJADA, Francisco, La monarquía tradicional (Madrid, Rialp, 1954) pp. 11-168 y Elías de Tejada, Francisco, Poder y autoridad: concepción tradicional cristiana, en AA.VV., Poder y Libertad (Madrid, Speiro, 1970), pp. 157-175.

19 Alvaro D'Ors enriquece la perspectiva tradicionalista con categorías romanas, sin perjuicio de la atención al modelo de la Cristiandad. WiLhelmsem, Frederick D., La filosofia politica de Alvaro D'Ors, en Glossae: Revista de Historia del Derecho Europeo 4 (1992), pp. 152-189. Su obra más representativa en la materia es D'Ors, Alvaro, Gabriel o del Reino, en El Mismo, Ensayos de Teoría Política (Pamplona, Eunsa, 1979), pp. 261-300; D'Ors, Alvaro, Autonomía de las personas y señorío del territorio, en cit., pp. 241-259; D'Ors, Alvaro, Legitimidad, en cit., pp. 135-152; D'Ors, Alvaro, Doce proposiciones sobre el poder, en cit., pp. 111-121; D'ORs, Alvaro, Forma de gobierno y legitimidad familiar, en EL MISMO, Escritos varios sobre derecho en crisis (Roma-Madrid, CSIC, 1973), pp. 121-138; D'Ors, Alvaro, Autoridad y Potestad, en El Mismo, Escritos varios sobre derecho en crisis (Roma-Madrid, CSIC, 1973), pp. 93-108; D’Ors, Alvaro, Nueva Introducción al estudio del derecho (Madrid, Civitas, 1999), pp. 71-73.

${ }^{20}$ Los vínculos sustanciales de Gambra con el tradicionalismo político hispano, en Ayuso, Miguel, Rafael Gambra en el pensamiento tradicional, en AA.VV., Comunidad humana y tradición política. Liber Amicorum de Rafael Gambra (Actas, Madrid, 1998), pp. 19-33; D’Ors, Álvaro, Rafael Gambra y Europa, en cit., pp. 69-77; SANTA Cruz, Manuel, Rafael Gambra y el carlismo, cit., pp. 79-87. Para la inserción de Gambra en los problemas de su época, Ayuso, Miguel, Koinós. El pensamiento político de Rafael Gambra (Madrid, Speiro, 1998), p.11-107 
Hay que connotar que la tesis de Gambra que revisaremos se inserta dentro de aquella corriente de la filosofía política que Compagnon denomina "anti-moderna" 21 y que Grossi extiende al ámbito jurídico ${ }^{22}$. El pensamiento "anti-moderno" recoge un influjo de doctrinas y actitudes filosóficas disímiles, anudadas por la crítica a la herencia político-jurídica de la Revolución Francesa ${ }^{23}$. La advertencia es importante pues permite comprender por qué Gambra, en su tesis sobre el "Reino", hace uso no sólo de la tradición política central cimentada en Aristóteles, Platón, Cicerón o Santo Tomás de Aquino, sino también de la filosofía "anti-moderna" de su época, particularmente el bergsonianismo, el existencialismo cristiano, la filosofía de la conciencia, y el posmodernismo ${ }^{24}$. Todo ello le sirve para anudar una proyección original de la veta tradicionalista en la propuesta del mejor régimen político y en la evaluación negativa del sistema político contemporáneo..

${ }^{21}$ Una actualizada caracterización de la conocida tipología en COMPAGNON, Antoine, Los antimodernos (Traduc. de Manuel Arranz, Barcelona, Acantilado, 2007), pp. 11-253 y en Goulemot, Jean-Marie, Adieu les philosophes: que reste-t-il des Lumières? (París, Seuil, 2001), pp. 98-106. Para un análisis del tópico en Gambra, Castellano, Danilo, La politica anti-moderna de Rafael Gambra, en AA.VV., Comunidad humana y tradición política, cit (n²0), pp55-67 y Millán Puelles, Antonio, Compromiso y razón. En torno a la figura intelectual de Rafael Gambra, en AA.VV., Comunidad humana y tradición política, cit., pp35-45.

${ }^{22}$ Grossi, Paolo, Mitología jurídica de la Modernidad (Madrid, Trotta, 2003), pp. 15-93. Un estudio sobre el "anti-modernismo" jurídico de Gambra, en VALLET DE Goytisolo, Juan, La obra de Rafael Gambra desde la Filosofía del Derecho, en AA.VV., Comunidad humana y tradición política, cit (n²0), pp. 93-107.

${ }^{23}$ La Revolución Francesa como el "pandemónium” del pensamiento político anti-moderno en sus distintas variables (tradicionalista, conservador, romántico, etc.), en Nisbet, Robert, Conservadurismo (Madrid, Alianza, 1995), pp. 13-26, 39108 y Compagnon, Antoine, Los antimodernos, cit (n²1), pp. 29-63. Un estudio de la Contra-Revolución en Francia en Tulard, Jean (Dir.), La Contre-Révolution. Origines, historie, postérité (París, Perrin, 2013), pp. 9-527. Para la Revolución Francesa en sí mismo considerada, Dawson, Christopher, Los dioses de la Revolución (Madrid, Encuentro, 2015), pp. 29-209, con introducción original de Arnold Toynbee; y Furet, Francois, La Revolución Francesa en debate (Buenos Aires, Siglo XXI, 2016), pp. 17-175.

${ }^{24}$ Para la influencia de estas corrientes, Forment, Eudaldo, Gambra intérprete de la crisis existencialista, en AA.VV., Comunidad humana y tradición politica, cit $\left(\mathrm{n}^{\circ} 20\right)$, pp. 109-129; Montejano, Bernardino, Saint-Exupéry visto por Rafael Gambra, en cit., pp. 131-145; Serrano, José Miguel, Gambra y el reencuentro del tiempo, en cit., pp. 183-193. Por el contrario, el autor discrepa fuertemente de Ortega y Gasset y recoge al segundo García Morente. Los estudios en Rodríguez, Victorino, Gambra en la polémica del orteguismo católico, cit., pp. 147-159 y ArTIGAS, José, La huella de García Morente, cit., pp. 161-181. 
En tal cuadro, analizamos, en primer lugar, la gran crítica que el autor dirige al pensamiento político moderno, que cristaliza en el racionalismo como su momento culminante. En segundo lugar, estudiamos lo que considera su expresión más peligrosa: el liberalismo, que conduciría a las sociedades a una situación a-política calificada como "exilio". Luego abordamos los principios constitutivos del "Reino", en cuanto régimen opuesto al "Estado", el gran artificio de la modernidad racionalista. Finalmente, se considera la figura del Rey como representante de la comunidad política y principio político ejemplar del "Reino".

\section{El RaCionalismo político}

Cuando se habla de "Reino" se formula un modo de concebir la política y la sociedad diametralmente opuesto al representado por el Estado moder$\mathrm{no}^{25}$. La gran preocupación de Gambra en este punto es el racionalismo, como núcleo teorético de dicho artificio político ${ }^{26}$.

A su juicio, el racionalismo trasciende los sistemas teóricos que lo expresan. Es una cosmovisión (en el sentido de Weltanschauung), una actitud de alma, un estilo, que sustituye al cristianismo, y que a lo largo de los siglos XVII, XVIII y XIX, en sus diversas zonas de influencia, tiene un ascendiente análogo al que tuvo la "concepción teísta" en el mundo medieval. Ascendiente de significado invertido, pues aquella concepción se traduce en el ensayo moderno de asignar a la obra de la razón humana los atributos que se le imputaban al Dios Cristiano. No solo en el sentido que Carl Schmitt daba a la secularización ${ }^{27}$. El racionalismo tiene una significación más honda: el proyecto de superación del carácter contingente del ser humano y del orden de lo creado. "Obedeciendo a ese impulso hostil al teocentrismo, (el racionalismo) pretendió trasladar esa condición de ser

${ }^{25}$ Para el Estado como formación específica de la modernidad política, JELLINEK, Georg, Teoría General del Estado, (traducción de Fernando de los Ríos Urruti), de Comares, Granada, 2000, pp. 55-56 y 319-458; Jouvenel, Bertrand de, Los orígenes del Estado moderno. Historia de las ideas políticas del siglo XIX, (Toledo, Emesa, 1977), p.14-240; Negro, Dalmacio, La tradición liberal y el Estado (Madrid, Unión Editorial, 1995), pp. 30-254.

${ }^{26}$ El más conocido análisis del racionalismo político es el de OAKESHOTT, Michael, Rationalism in Politics, (London, Methuen, 1962), pássim. Gambra, sin embargo, lo precede cronológicamente.

27 Schmitt, Carl, Teología politica, en El mismo, Estudios politicos (Traducción de Francisco Javier Conde, Madrid, Doncel, 1975), p.65-79; Schmiтt, Carl, La época de la neutralidad, en El MISMO, Estudios politicos, cit., pp. 11-31. 
necesario desde Dios al mundo en que vivimos, no a cada cosa, sino al mundo considerado como unidad", precisa Gambra ${ }^{28}$.

Tal sería el núcleo teorético radical, la creencia más íntima del racionalismo. Una transmutación de la base metafísica que otrora sirvió a Tomás de Aquino para componer la Tercera Vía de la existencia de Dios. Gambra lo formula a modo de principio basal: "La realidad no es una cosa contingente que recibió la existencia y necesita de un ser necesario como causa, sino, en su ser total, es un ser necesario, al que descansa en sí mismo y se explica por si'"29.

Este modo de concebir el orden del ser y del obrar influye en toda la gama de teorías políticas construidas bajo su influjo. En primer lugar, la creencia de que la realidad no se halla asentada sobre unos datos contingentes, sino sobre el desenvolvimiento de una estructura racional necesaria. En segundo término, el logicismo absoluto que considera la relación entre los seres como un autodesarrollo abstracto de la Idea, singularizada en alguna categoría política (Estado nación, pueblo, raza, clase, etc.). Tercero, la simplificación de la realidad (lo superior se reduce a lo inferior), por obra de una razón que en busca de la evidencia se reduce a la sola medición cuantitativa. Cuarto, el ideal del progreso científico como clave para la interpretación del sentido de la historia, tras lo cual se halla el sueño del conocimiento omnicomprensivo o total de la realidad, donde todo aparecerá como necesario ${ }^{30}$.

Dado que los sistemas filosóficos tienen un correlato en el orden político-social, puede vislumbrarse cómo las características anteriores modelan el "estilo" de lo que podemos llamar "racionalismo político": desprecio por las realidades concretas y personales, adhesión o imposición de sistemas cerrados como ámbito de la política, y destierro de la prudencia como virtud rectora ${ }^{31}$.

${ }^{28}$ Gambra, Rafael, Historia sencilla de la filosofía (Madrid, Rialp, 1999, 24 ed.) p.151.

${ }^{29}$ Gambra, Rafael, Historia sencilla de la filosofía, cit. (n.18), p.152.

${ }^{30}$ Gambra, Rafael, Historia sencilla de la filosofía, cit. (n.18), pp. 150-153; GAMBRA, Rafael, La moral del existencialismo, en Revista de Filosofia 42 (1952) pp. 401430. El autor aprovecha, aunque no lo suficiente, la contestación "posmoderna" al racionalismo fundada en la crítica de la razón instrumental o calculadora, que transforma al hombre en "déspota del ser", como decía Heidegger, Martín, Carta sobre el humanismo (trad. A. Wagner de Reyna, Santiago, Universidad de Chile, 1953), pp. 187 y 201. En este sentido, D’Agostino, Francesco, Filosofia del diritto (Torino, Giappichelli, 1993), pp. 111-127 y KaUfmann, Arthur, La filosofia del derecho en la posmodernidad (Bogotá, Temis, 1992) pp. 6-7. Sobre el "cientificismo", GAMBra, Rafael, El García Morente que yo conocí (aquella extraordinaria irrupción de la gracia), en Nuestro Tiempo 32 (1957), pp. 145-150.

${ }^{31}$ Gambra, Rafael, Eso que llaman Estado (Madrid, Montejurra, 1958) pp. 20- 
Gambra presta mucha atención a la génesis y desarrollo del racionalismo político, como vía privilegiada para comprender su naturaleza. En este punto, abre horizontes críticos comparables a los planteados por Voegelin y Oakeshott, a quien no parece haber conocido. El autor, sin embargo no es sistemático. A momentos, en exceso descriptivo. Puede componerse, no obstante, una síntesis con los siguientes elementos:

1. La Revolución Francesa es la gran obra del racionalismo político, que proyecta sus instituciones hasta los días de hoy. El autor rechaza la "tesis catastrofista" sobre este acontecimiento, proponiendo una comprensión evolutiva. Dicha revolución no sería el inicio, sino el culmen de dos procesos que entran en conjunción: la racionalización cultivada por la Ilustración y el espíritu revolucionario difundido por Rousseau. El primero tiene ribetes gnósticos, en cuanto postula que las diversas creencias que han dominado a la humanidad son representaciones burdas de una más profunda verdad, la comprensión racionalista, "científica", del mundo, que ha de iluminar a los hombres. Tal iluminación porta el sentido último de la historia, que se expresa en el progreso, como faceta definitiva de la racionalización de todo lo existente. La teoría se vuelve práctica por el impulso de Rousseau. La "era racional" no se logra por lenta evolución, como quieren los enciclopedistas, sino por violenta revolución. La irracionalidad y sus productos culturales, sociales y políticos no son un estrato previo sujeto al cambio sino la misma causa del mal que es imperativo extirpar. De ahí la violencia para arrumbar el orden no racionalista, con métodos y técnicas particulares, inherentes a la revolución moderna, capaz de imponer un proyecto minoritario a la mayoría de la sociedad ${ }^{32}$.

2. El poder constituyente, que emerge con la Revolución Francesa, es, en cuanto artefacto racionalista, funcional a un designio hondamente destructivo: el ensayo de demolición de la estructura político-social existente, considerada mero producto de un pasado irracional y causa ambiental de la perversión del hombre. De ahí el simbólico decreto de la Asamblea Nacional francesa, del 17 de julio de 1791, por la que se prohíben las corporaciones, y tras ellas, las autonomías asociativas y las instituciones políticas locales, con sus peculiaridades históricas. Todo lo que no figure en la nueva constitución racionalista, impuesta desde el más alto escalafón del poder, debe ser eliminado. En este horizonte, "las constituciones politicas simbolizan el momento en que la razón humana, saltando violentamente por

22, 32, 70-72; Gambra, Rafael, La moral existencialista y los cauces de su posible superación, en Anales de la Real Academia de Ciencias Morales y Políticas 2 (1955) pp. 246-256.

${ }^{32}$ Gambra, Rafael, La monarquía social y representativa en el pensamiento tradicional (Madrid, Rialp, 1954), pp. 50-52. 
encima de los ídolos y prejuicios que la historia y la rutina habian opuesto a la marcha del progreso, se instala sobre la vida de los hombres a fin de dirigirla por cauces justos y definitivos"33.

3. La obra política de la Revolución Francesa, como paradigma de la modernidad, consiste en imponer una centralización estatal uniforme, cuyas líneas generales se establecen en las constituciones de las nacientes sociedades racionalistas. Esto significa que la gran criatura del racionalismo político es el "Estado racional", abocado durante el siglo XIX, en razón de su propia lógica, a dos importantes resultados: arrumbar todas las instituciones políticas que no deriven de sí mismo y asfixiar las autonomías sociales de manera de dejar solo dos autonomías: el Estado y el individuo. El liberalismo sirvió de justificación positiva a esta obra eminentemente negativa. Según las nuevas ideas, las instituciones intermedias coartan las libertades ${ }^{34}$.

4. Con el Estado, el racionalismo político crea un poder político inmenso, excesivo, asimilable al Leviatán, o al Minotauro, como le llama Jouvenel ${ }^{35}$. Gambra coincide con Nietzsche en la consideración del Estado como el más frío de los monstruos fríos ${ }^{36}$. Se trata de un poder absoluto a varios títulos. Porque reivindica la ilimitación jurídica de la soberanía (burguesa o popular, según los tiempos). Porque tal soberanía la asume de manera completa y total, por exigencia ideológica e histórica (disolución de todo cuerpo social autónomo; rechazo de ascendientes naturales, consuetudinarios o morales que impongan una norma). Porque usurpa, arranca o invade las prerrogativas de las personas individuales y colectivas. En fin, es un poder absoluto porque extingue la función tutelar, arbitral y parlamentaria de la antigua potestad política, y la transforma en un poder centrípeto, por absorción o sustitución de la sociedad. "Este Estado, puntualiza el autor, en su nueva concepción, dejará de ser la autoridad política-el poder-que viene de Dios y tiene como misión velar por la justicia y la armonía de la sociedad, y se convertirá en la sociedad misma, sin otra organización

33 Gambra, Rafael, La monarquía, cit. (n.22), p.54.

${ }^{34}$ Gambra, Rafael, La monarquía, cit. (n.22), pp. 54-55. Gambra sigue de cerca a Vázquez de Mella, Juan, Sintesis de las doctrinas liberales. Discurso al Parlamento del 31 de mayo de 1893, en El Mismo, Obras Completas (Madrid, Junta de Homenaje a Mella, 1932), t. XI, p.43.

35 Gambra, Rafael, Prólogo a Jouvenel, Bertrand de, El Poder (Madrid, Editora Nacional, 1956), pp. 7-14. Sobre el absolutismo del poder estatal moderno, GAMBRA, Rafael, La monarquía, cit. (n.22), pp. 61-63.

${ }^{36}$ NieTzSCHe, Friedrich, Asi habló Zaratustra, II, 11, Del nuevo ídolo. 
politica que la propia organización estatal'37. La administración del Estado racional es, per diametrum, lo opuesto al gobierno del Reino ${ }^{38}$.

Las limitaciones imaginadas por el liberalismo son todas mecánicas y no han resultado efectivas, al menos si se mira el poder del Estado en su conjunto, que no ha hecho más que crecer. Lo ilustra la doctrina de la división de poderes que poco ha servido. Expresa Gambra que, supuesto el poder soberano, tal división no garantiza las libertades reales y concretas. El tránsito del Estado liberal al Estado socialista es, desde esa perspectiva, una cuestión de grados, no de naturaleza.

La justificación racionalista de la legitimación democrática tampoco es útil para resolver el problema de la entidad del poder moderno. En rigor aquella ha reducido la participación popular a los solos actos electorales, que, en definitiva, tienden a transmutarse en actos exteriores y ocasionales de carácter ritual ${ }^{39}$.

5. La soberanía política es en todo funcional al racionalismo: se convierte en la instancia superior racional (concretada en el Estado o la nación) que hace de único principio unificador y estructurador del orden político y de la convivencia humana. La organización geométrica que impone no considera el dinamismo de las leyes materiales de la vida social. Se crea, de este modo, la sociedad "oficial", única colectividad con la que dialoga el Estado. Opuesta a la coexistencia de sociedades e instituciones autónomas respecto del poder público, la sociedad "oficial" es regida por patrones y sistemas reglamentarios ${ }^{40}$.

6. El racionalismo político ha generado, por el dinamismo de su propia

${ }^{37}$ Gambra, Rafael, La monarquía, cit. (n.22), p.55

38 Precisa Gambra que "en la antigua sociedad, se partía de la dualidad rey-república, o el principe y sus Estados, y se concebía el poder del rey como el guardador del derecho de los hombres y de los grupos. Asi el rey parlamentaba con sus reinos o ciudades, los escuchaba, discutía con ellos. El Rey debía regir sus Estados, pero éstos tenían por sí mismos una organización, o más bien, eran un conjunto de estamentos o instituciones cuya estructura no solo era asunto de la propia sociedad, ajena, por tanto a la voluntad del rey, sino que se consideraba como un orden natural, una estructura objetiva". GAMBRA, Rafael, La monarquia, cit. (n.22), pp. 55-56.

39 Gambra, Rafael, La monarquía, cit. (n.22), pp. 47-49, 59-63, 81-84. El autor utiliza varios contra-ejemplos para probar la futilidad de la división de poderes. Argumenta que aún con dicha división, en la Europa del siglo XIX, el Estado liberal pudo servirse de un poder sin límites para desarticular lo común de las instituciones económicas básicas. Remite especialmente a la desamortización de las propiedades municipales y gremiales, base de la previsión social; a la desvinculación de la propiedad respecto de las relaciones comunitarias y afectivas, y al subsiguiente fomento de la concentración anónima y su uso impersonal para fines puramente especulativos. GAMBra, Rafael, La monarquía, cit. (n.22), p.48

${ }^{40}$ Gambra, Rafael, La monarquia, cit. (n.22), pp. 67, 82-88. 
evolución, el fenómeno del totalitarismo. La vía que ocupa Gambra para explorar esta dimensión es bastante peculiar, al menos si se la compara con otros referentes como Talmon, Jouvenel y Arendt. Su principio es de naturaleza socio-política: la sociedad organizada "racionalmente" en la medida que se desarrolla según sus propios axiomas se aparta necesariamente del hombre real y concreto y su real impulso asociativo.

El "apartamiento" encuentra su origen lógico en la doctrina abstracta, anti-natural y a-histórica del pacto social, que legitima teóricamente la nueva organización racional. El autor no concede importancia a los diversos contextos ideológicos que plasman dicha doctrina. Pueden girar, sin problema, desde el extremo individualista al colectivista. Lo que interesa es el fenómeno desnudo, vital, del "apartamiento". A partir de ahí, toda la serie de divagaciones sobre el pacto social, cualquiera sean las fórmulas concretas que adopte, llevan imbricadas la misma dificultad: el que la sociedad civil y política ha sido declarada "inesencial", accesoria a la naturaleza del individuo. In to to, es fruto del acuerdo o pacto entre individuos libres e iguales. O sea de la voluntad racionalista. Es un artificio que ya no depende de nada previo.

El poder y la ley proceden, en adelante, de la voluntad del mayor número, "expresada empíricamente en el sufragio", recalca el autor, para acentuar el momento liberal. Pero como la voluntad popular se expresa, en definitiva, por medio del Estado, estructura política centralizada y omnipotente, basta considerar su ejecutoria para llegar al momento socialista: de la suma de las voluntades individuales a la expresión de la voluntad colectiva representada por la nación, la raza, o el proletariado. Entonces, el poder total del Estado se ejerce no en atención al individuo abstracto, sino a una categoría abstracta. El imperativo liberal del "Estado gendarme sin consigna" decrece. Mientras acrece el imperativo colectivo del Estado portador y realizador de valores totales, que moldea a voluntad al individuo ${ }^{41}$.

7. El racionalismo político, considerado en su conjunto, más allá de sus distintos momentos, es una revolución contra la sociabilidad humana, particularmente contra su base natural. La sociabilidad es una síntesis de tendencia nativa, instinto y voluntad racional. En la formación de un régimen político colaboran razón, instinto y ciega adaptación natural, por lo que su organización no puede ser resultado de la sola razón, y además, en exclusiva, de la razón razonante.

${ }^{41}$ Gambra, Rafael, La monarquía, cit. (n.22), pp. 76-77. Gambra, Rafael, La unidad religiosa y el derrotismo católico. Estudio sobre el principio religioso de las sociedades históricas y en particular sobre el catolicismo en la nacionalidad española (Sevilla, Editorial Católica, 1965), pp. 13-14 
La mirada del racionalismo político reduce el inmenso y complejo potencial de la sociabilidad, hurtándole su vitalidad interior, sus modos de adaptación y auto-gobierno, no reducibles a los fríos esquematismos de uniformidades abstractas y predeterminadas. La sociedad no es obra única de organizadores y leyes formales, sino también de elementos comunitarios y aglutinantes que calan en todos los estratos ónticos del ser humano. El racionalismo político sujeta a todos estos estratos a la camisa de fuerza de los organismos oficiales que carecen, en general, de sentido de comunidad, plegados a la lógica exterior del funcionariado. Una institucionalidad de cáscara, que, venganza contra lo anti-natural, es condenada a un continuo "tejer y destejer", cual es la historia de la mayor parte de los Estados europeos y americanos, donde la "revolución pendular" pasa a ser el "estado normal de vida" ${ }^{42}$.

8. Las distintas versiones del racionalismo político resultan en todo caso impositivas para el ser humano, porque produce sistemas absolutos en el que "toda realidad queda prendida en la mallas de la razón pura y su devenir incierto se convierte en fases dialécticas de un todo racional"

En este plano, y profundizando la línea abierta por Villey ${ }^{44}$, la acusación más grave que formula Gambra al racionalismo político es su pretensión, operada en diversos grados, de desmantelar la realidad humana para construir (re-crear) un nuevo estado de cosas, enteramente funcional a sus presupuestos teóricos, pero que, en definitiva, en cualquiera de sus versiones, tiende a resultar inhumano.

9. Hay una suerte de ignorancia fingida del racionalismo político respecto de su propia crisis. Como movimiento general dicha crisis es situada por el autor en el tránsito del siglo XIX al XX, y tiene su origen en la nueva concepción del tiempo y del espacio de la ciencia (Planck, Heisenberg, Einstein), de la filosofía (fenomenología, existencialismo) y de la historia, donde un conjunto de hechos imprevistos se imponen a la sociedad organizada "racionalmente", planteando problemas que la razón ya no puede dominar (el maquinismo, la masificación, el poder totalitario y la guerra como punto de fracaso de los tres racionalismos políticos soñados:

42 Gambra, Rafael, La monarquía, cit. (n.22), pp. 63, 79-80, 113-114, 123-124.

${ }^{43}$ Gambra, Rafael, Eso que llaman Estado (n.21), p.71.

44 VILley, Michel, La formation de la penseé juridique moderne (Paris, Montchrétien, 1975, Nouvelle édition corrigée), en lo atinente al paradigma hobbesiano descompositivo y recompositivo. 
el liberal, el nacionalista y el internacionalista $)^{45}$. Lejos las esperanzas del planteamiento positivista del progreso indefinido ${ }^{46}$.

Este conjunto de variables parecen probar que la estructura más radical de la realidad escapa a todo intento de racionalización, porque es contingente, fáctica, existente. Es esquiva en someterse al dominio de la razón racionalista y su pretensión matemática de necesidad y totalidad.

La inhumanidad y la inviabilidad de la obra política del racionalismo quedan expresadas oportunamente en la idea de "exilio", el estado de destrucción y sustitución que impone el constructo racionalista a la sociedad moderna, y que, como veremos, el autor atribuye con especial énfasis al liberalismo.

III. Auscultando el liberalismo político. El "exilio"

Pese a su crisis, el racionalismo mantiene un influjo omnipresente en el espacio político gracias al paradigma del constitucionalismo y la democracia liberal (o socialista, según los casos). In genere, son formas de organización humana que no reconocen la contingencia en sus respectivos ámbitos. De ahí la organización burocrática de los Estados modernos y la rigidez del derecho funcionarial, que excluyen la multiforme ductilidad de la autonomía social, de suyo abierta al vínculo y al compromiso, precisamente en razón de su contingencia.

Gambra estudia lo que podríamos llamar el "espíritu” del liberalismo. Salvo en Locke, no se detiene en el detalle de ninguno de sus teorizadores políticos. Más bien analiza la cuestión en los denominadores comunes del fundamento teorético.

De este modo, concibe el liberalismo racionalista como fruto del designio ilustrado y del espíritu revolucionario de crear un mundo nuevo a partir de las cenizas del orden antiguo, considerado irracional y arbitrario. Sus distintas conformaciones políticas (constitucionalismo, separación de poderes, democracia representativa primero burguesa, después de masas) se van colocando como piezas de un dominó en la medida en que el poder político moderno -el Estado "racional"- se vuelve capaz de someter la realidad social.

Tales configuraciones adoptan un cariz destructor y otro mistificador.

Desde la perspectiva de la historia de las instituciones, la faceta demoledora se manifiesta en el proceso de "desvinculación" llevado a cabo por

45 Gambra, Rafael, Eso que llaman Estado, cit. (n.21), p.72; Gambra, Rafael, Historia sencilla de la filosofía, cit. (n.18), pp. 255-262.

${ }^{46}$ Gambra, Rafael, La aceleración de la historia y el progresismo católico, en Verbo 33 (Madrid), 1965, pp. 171-185; Gambra, Rafael, El mito del progreso, en Verbo 73 (Madrid), 1969, pp. 159-177; Gambra, Rafael, El Movimiento de la historia, en Verbo 235 (Madrid), 1985, pp. 583-593. 
el Estado a partir de la Revolución Francesa. Según adelantamos, el individualismo abstracto e igualitario sirve de ideal para fundar la demolición progresiva de todos los cuerpos asociativos autónomos entre el individuo y el Estado (patrimonios familiares, gremios, universidades, municipios con bienes propios, administraciones regionales, etc.). La persona de carne y hueso es convertida en ciudadano, átomo indistinto, elemento singular sobre el cual el poder estatal de-construye y construye la sociedad nueva.

Derruido el vasto campo de las personas vinculadas y de los cuerpos intermedios, se priva al orden social de su estructura propia y de sus principios vitales internos. El poder moderno, aunque profese de liberal, queda sin estructura social viva y autónoma que lo contenga. El individuo formalmente solo ante el Estado ${ }^{47}$.

En continuo con las explicitaciones de Vogelsang, Tocqueville y Vázquez de Mella, nuestro autor caracteriza los males sociales del liberalismo: espíritu individualista, anti-comunitario y sobre-estimador de la libertad individual. Sin embargo, el fruto más nocivo del sistema sigue siendo de carácter político: la destrucción del "sociedalismo" natural e histórico. El liberalismo niega en este punto una verdad esencial: el "poder natural" que tienen los hombres y las sociedades para organizarse y adaptarse de acuerdo a la ley natural prolongada en la historia ${ }^{48}$. Esta triple negación -de la naturalidad, de la vitalidad y de la historicidad de la sociedad políticaes sustituida por el apriorismo ideológico de un sistema fundado en el individuo abstracto, inexistente, sujeto de una libertad también abstracta y uniforme ${ }^{49}$.

El constructo no se sostiene. Si la auténtica comunidad política es efecto natural de la sociedad, los sistemas racionalistas (como el Estado liberal) son imposiciones de ideólogos y aprioristas. De ahí la necesidad de mistificación. En varios grados. El régimen liberal se funda en la opinión, en la duda, o, si se quiere, en el principio de que nada es verdadero en materia política. Por ello necesita, en un primer grado, de ideologías y de partidos, y de toda la estrategia que le acompaña para fijar las opiniones:

47 Gambra, Rafael, Eso que llaman Estado, cit. (n.21), p.34. La desvinculación como proceso histórico-político, en GAMBRA, Rafael, La monarquía, cit. (n.22), pp. 69-85.

${ }^{48}$ Gambra utiliza el concepto de "naturaleza" de acuerdo a la doctrina de Santo Tomás. Lo natural no equivale a lo puramente instintivo, tendencial o espontáneo. Supone el respeto y la atención por esta base biológica, pero rectificada por la finalidad racional, de acuerdo a los distintos ámbitos de actividad. Para una precisión sobre este punto, SpaEmann, Robert, Lo natural y lo racional (Santiago, IES, 2009), pássim; PuY, Francisco, Teoría Tópica del Derecho Natural (Santiago, Universidad Santo Tomás, 2004), pp. 25-32.

49 Gambra, Rafael, La monarquía, cit. (n.22), pp. 56-57, 200 y 215. 
manipulación del lenguaje, sustitución del concepto por el slogan y la nueva sofística del razonamiento pueril (basada en el uso de términos estereotipados).

Hay, sin embargo, un estrato más profundo. El de la significación mítica del racionalismo. Sostiene el autor, en una de sus obras más profundas, que éste operó "el retorno de lo irracional, la irrupción del mythos - de una nueva mitología y una nueva magia-sobre el mundo de los hombres ${ }^{` 50}$. Al negar lo sagrado, la mente y el lenguaje humano se mitifican de nuevo, perdiendo la nitidez de lo diferenciado. Hoy vivimos bajo "la constante influencia perturbadora del saber figurativo y mágico", es decir, la sustitución del logos por el mythos ${ }^{51}$. Las teorías políticas liberales se asumen como si fueran parte de la realidad, sin preocupación por discernir su contraste con ésta.

Llegamos así al "exilio", utilizado como metáfora para describir la situación de desarraigo e inestabilidad que produce el racionalismo político en general, y el liberalismo en particular ${ }^{52}$. La categoría del "exilio" no es objeto de análisis sistemático. Sin embargo está presente de modo explícito, y las más de las veces de forma implícita, en la mayor parte de las críticas que el autor dirige al sistema político liberal, al menos en cuanto su médula depende del racionalismo.

La idea de exilio hay que comprenderla adecuadamente. Gambra explora el filón anti-positivista y anti-idealista abierto por Kierkeggard, Unamuno y el existencialismo, para constatar, en primer término, la inviabilidad del racionalismo en su raíz. La fe en un "universo autoexplicativo e indefinidamente penetrable por el progreso de la razón" está condenada al choque con la realidad en forma de malestar, inhibición o rebeldía. De ahí la emergencia de la filosofía de la angustia, de la soledad, del riesgo, de la extrañeza ante un existir no predeterminado, completamente arrojado a sí mismo. Aparece nuevamente, ahora desde una óptica subjetiva, la certeza de la inanidad de la razón racionalista ante el ritmo continuo de la contingencia de los seres ${ }^{53}$.

En este cuadro tan típico, a la razón humana no le queda más que re-

${ }^{50}$ Gambra, Rafael, El lenguaje y los mitos (Madrid, Speiro, 1983), pp. 40-41.

${ }^{51}$ Gambra, Rafael, El lenguaje y los mitos, cit. (n.39), p.28-29.

${ }^{52}$ La idea se construye de la mano de Camus y de Saint-Exupéry, Gambra, Rafael, La última posición de Camus, en Arbor 98 (1954), pp. 135-142; GAMBRA, Rafael, Rebelión y Revolución en la obra de Camus, en Nuestro Tiempo 69 (1960), pp. 120130; Gambra, Rafael, El exilio y el reino, en Verbo 231-232 (1984), pp. 73-94; GAMBRA, Rafael, La ciudad humana de Antoine de Saint Exupéry, en Atlántida 5 (1963), pp. 503-524. Desde el ángulo de las relaciones puramente societarias, y no políticas, el "exilio" tiene equivalencia con lo que el autor denomina "el mal social". Gambra, Rafael, El mal social, en Revista Internacional de Sociología 46 (1954), pp. 219-228.

${ }^{53}$ Gambra, Rafael, El exilio y el Reino, cit. (n.41), pp. 73-76. 
conocer su "incapacidad para penetrarlo todo sin residuo". Se dibujan dos caminos. Uno, el de la pérdida o abandono de los asideros cognoscitivos y vitales del discurso, línea sobre la que avanza la posmodernidad. El otro camino es el que reivindica Gambra: atención, respeto y compromiso por el orden natural inserto en la historia, categoría que somete a nuevas claves de explicitación, hasta fundar, como veremos, la noción de "Reino", opuesta a la de "exilio".

Exilio es lejanía, abandono, intemperie, disociación vital, distancia existencial respecto de la genuina comunidad social ahogada, enajenada, extinguida por los modernos. Exilio es también estado de a-politicidad al que conduce, por paradoja, el espacio político que llamamos liberal. Se le puede reconocer por algunas notas características:

1. Desaparición del mundo extenso y cordial de las instituciones históricas, por destrucción de las autonomías sociales o absorción de la sociedad por el Estado ${ }^{54}$.

2. Tragedia de inadaptación ante fuerzas que el hombre ha desatado con la racionalización política. Los efectos más visibles: impotencia del individuo frente al poder ilimitado del Estado ${ }^{55}$; exterioridad uniforme y coactiva del derecho público en la reglamentación de la vida social ${ }^{56}$; anomia ante el destino común de la comunidad política ${ }^{57}$; desarraigo de la sociedad, con la subsecuente deshumanización de las relaciones laborales y económicas ${ }^{58}$.

${ }^{54}$ Gambra, Rafael, La monarquía, cit. (n.22), pp. 79-80.

55 Gambra, Rafael, La monarquía, cit. (n.22), pp. 58-59. Como se ha adelantado, Gambra considera el liberalismo y el totalitarismo etapas de un mismo proceso de desvinculación. En ambos casos la sociedad ha huido del hombre, se ha desvinculado de su realidad y sustancia, llegando a hipostasiarse en un poder absorbente cuyos límites y fines resultan inasequibles a toda humana previsión. GAMBRA, Rafael, La monarquía, cit. (n.22), p.77.

${ }^{56}$ Gambra, Rafael, La monarquía, cit. (n.22), pp. 49-50.

${ }^{57}$ Gambra, Rafael, La monarquía, cit. (n.22), pp. 69-70

58 El maquinismo, la destrucción del localismo institucional y el economicismo, han convertido el trabajo en mero vehículo de lucro (que se hipertrofia en un ambiente que desconoce el sentido tradicional de servicio o de perfección) o en funcionarismo (neutralidad mecánica tan apegada al reglamento, como ajena al interés de la obra misma). GAMBRA, Rafael, La monarquía, cit. (n.22), pp. 77-79. En la línea de Gustave Thibon y Simone Weil, se critica ásperamente el liberalismo económico por romper el vínculo personal entre el autor y su obra, por la reducción de las fuerzas económicas a la primitiva auto-conservación existencial, y por la indefensión del débil. Gambra, Rafael, El problema de las clases directoras en la sociedad contemporánea, en Revista Internacional de Sociología 18 (Madrid), 1947, pp. 364-367. 
3. Existencia de realidades políticas descarnadas, representativas de unidades absolutas y abstractas (Estado, Derecho, Libertad) ${ }^{59}$.

4. Aparecimiento del hombre nuevo, sujeto de individualización o revolución y no de edificación ${ }^{60}$.

Desde este horizonte se comprende una de las afirmaciones más controvertidas del autor: "La democracia liberal es la consagración oficial del exilio como forma permanente de gobierno e ideal humano: la negación de un cimiento estable para la sociedad, la extirpación de las raices, la supresión de los objetivos finales y de la trascendencia, la negación a priori de la sociedad como comunión en una fe y una esperanza, la eliminación de todo punto de referencia en la vida de los hombres. En la democracia moderna las convicciones se convierten en opiniones, el derecho en meramente positivo y circunstancial, y la autoridad en gerencia circunstancial'"61.

Gambra no entra, como D’Ors, Elías de Tejada o Vallet, a disputar con el liberalismo en su mismo terreno ${ }^{62}$. El asalto lo da desde fuera, cuestionando el racionalismo, el fundamento más nítidamente anti-metafísico del liberalismo. A partir de ahí le es más fácil someter a criba las categorías más caras al sistema, al menos en sus denominadores comunes. No cuestiona el discurso de la libertad oponiendo un concepto distinto de ella, sino destacando la inhumanidad de un atributo convertido en artificio. No rechaza la separación de poderes, sino su viabilidad como límite al poder estatal en creciente expansión. No controvierte el papel político del pueblo, sino la capacidad de la democracia inorgánica para canalizarlo ${ }^{63}$. No rechaza el

59 Gambra, Rafael, La monarquía, cit. (n.22), pp. 75-76.

${ }^{60}$ Gambra, Rafael, La monarquía, cit. (n.22), pp. 59-60. La edificación, o en términos del autor, la habitación política se construye sobre el patrimonio común de la sociedad, donde juega un papel fundamental el engagement y la apprivoisement. Gambra, Rafael, La ciudad humana, cit. (n.41), pp. 503-509.

${ }^{61}$ Gambra, Rafael, El exilio y el Reino, cit. (n.41), p.92.

${ }^{62}$ Vr. gr., en torno a la libertad, ELÍAS DE TEJADA, Francisco, Libertad abstracta y libertades concretas, en Verbo 63 (1968) pp. 149-166 y D'Ors, Alvaro, La libertad, en El mismo, Ensayos de Teoría Política, cit. (n.16), pp. 201-222. En torno al pacto social, VALLET De GoYTISOlo, Juan, Las diversas clases de pactismos históricos. Su puesta en relación con el concepto bodiniano de soberanía, en Anales de la Fundación Elías de Tejada 9 (2003), pp. 15-33. Gambra también analiza el problema de la libertad, pero culpa a la "sociedad de masas" de su devaluación. GAMBRA, Rafael, Libertad en la sociedad cristiana y en la sociedad de masas, en Verbo 84 (1970), pp. 283-300; GAMBRA, Rafael, Las raíces eternas de la libertad, en Verbo 261-262 (1987), pp. 185-189.

${ }^{63}$ De ahí la crítica a la representación política liberal como adulteración, GAMBRA, Rafael, La monarquía, cit. (n.22), pp. 74-75, 185-187, 200 y 215. Para la precisión de este punto, D'Ors, Alvaro, El problema de la representación política, en EL mismo, Ensayos de Teoría Política, cit. (n.16), pp. 223-240, y Galvao de Souza, José Pedro, La representación política (Madrid, Marcial Pons, 2011), pp. 25-119. 
individualismo como actitud espiritual, sino el individualismo moderno como principio político.

El individualismo "moderno" corresponde a uno de los designios ideológicos centrales del racionalismo liberal: desembarazar al "yo" de todo género de vinculación o instancia superior a la que servir o entregar. En esta concepción, que para el autor tiene un claro sabor gnóstico, la auténtica vida humana solo nace y se cultiva desde la ausencia de vínculos. A resultas, el individuo-ciudadano queda convertido en un "imaginario haz de potencias inactuadas", desembarazado del medio y de las realidades históricas en que por naturaleza se ha de hallar inserto en su ser y en su obrar ${ }^{64}$.

Al movimiento constitucionalista que surge con la Revolución Francesa el autor dirige la onerosa imputación que adelantamos pero que debemos precisar aquí: someter el poder natural humano de organización y adaptación histórica a los cánones fríos, uniformes y esquemáticos del normativismo abstracto. En adelante, la vida política dependerá en exclusiva de la organización "racional" impuesta desde arriba. Lejana queda la idea del orden político natural, necesitado de "holgura o amplitud existencial" para desarrollarse. En el esquema de la razón pura, no hay espacio para los lazos contingentes -más o menos misteriosos, impenetrables- que otorgan arraigo y sentido a la vida. Lo político es forzado a desenvolverse en los "esquemas apriorísticos" de la constitución escrita, cuyo éxito depende, sin embargo, del grado de aceptación o adaptación a la constitución histórica ${ }^{65}$.

Para la persona, el liberalismo es el horizonte político de las promesas incumplidas. La teoría proclama la autolimitación del poder, pero habiendo desaparecido el mundo social inasible al Estado, el "desarraigo" emerge irremediablemente ante la implosión y posterior atomización del destino colectivo.

Esta última acusación, tan común al comunitarismo anglosajón, es reformulada por Gambra desde un parámetro bastante original: la temporalidad. Sostiene que la progresiva desaparición de las instituciones vinculadoras produce un severo desajuste entre el tiempo oficial de los esquemas políticos liberales y el tiempo real de las personas individuales y colectivas. En su ser y en su obrar, éstas penden acompasadamente del

${ }^{64}$ Gambra, Rafael, La monarquía, cit. (n.22), pp. 70-73.

${ }^{65}$ Gambra, Rafael, El silencio de Dios (Madrid, Editorial Prensa Española, 1968), pp. 176-189; Gambra, Rafael, La monarquí, cit. (n.22), p.200. En nuestro medio, sobre la constitución histórica, Bravo Lira, Bernardino, El Estado de Derecho en la historia de Chile (Santiago, Ediciones Universidad Católica de Chile, 1996), pp. 9-60. También la supone, GUZMÁN BRITO, Alejandro, El derecho privado constitucional de Chile (Valparaíso, Ediciones Universitarias de Valparaíso de la Universidad Católica de Valparaíso, 2001), pp. 27-32. 
tiempo acumulativo y de la tradición vivida. El pacto social o la exterioridad de los contratos, paradigmas liberales, excluyen esta riquísima dimensión de la comunicabilidad política ${ }^{66}$.

En virtud de lo antecedente, queda claro por qué el autor denomina "exilio" al régimen liberal. Término, sin embargo, gradual, pues se aplica en la medida en que éste incorpora y modula los principios teóricos del racionalismo político y los hace cuerpo en la organización estatal y social. No parece estar en la mente de Gambra el querer referirse despectivamente al liberalismo en la acepción de tradición política de limitación al poder.

IV. El Reino: sus bases; su concreción

No encontramos una definición precisa de "Reino" en la obra de Gambra, al menos en términos político-jurídicos. Pero podemos deducir que es la comunidad política en la que se expresa el principio monárquico de la "reductio ad unum": la tendencia del todo social hacia lo selectivo, coronado por una dinastía gobernante ${ }^{67}$. La noción de comunidad política y de principio monárquico es genérica por lo que se hace necesario analizar su tipología: primero, la naturaleza del hombre, munida de politicidad; segundo, el régimen político que se desenvuelve a partir de ella; tercero, el Reino que lo concretiza.

El autor parte de la concepción aristotélica del hombre como animal social y político. En polémica con el racionalismo, sostiene que la naturaleza humana es una realidad extramental en donde se hallan "pre-formados" los impulsos sociales originarios y la estructura natural de la sociedad. Un núcleo misterioso y complejo, con leyes vitales propias de comunicabilidad y adaptación en el ser y en el obrar, que la razón no alcanza a comprender $\mathrm{o}$ a predeterminar del todo en cuanto a su especificidad, espontaneidad y carácter procesivo.

La "pre-formación" del orden social, y del político que lo corona, puede reconocerse de muchas maneras. Gambra trae a colación la teoría de las tres clases sociales de Platón para ilustrarla. También recuerda la doctrina de las tres tendencias naturales de Tomás de Aquino para connotar que se trata de impulsos específicos de la sociabilidad hacia la propia perfección.

Reformulando el pensamiento de los clásicos, el autor analiza el impulso de afectividad y continuidad que engendra la institución de la familia; el impulso económico material que determina las clases profesionales y la institución gremial; el impulso defensivo, del que surge la institución militar; el impulso intelectual, del que nace la agrupación universitaria,

${ }^{66}$ Gambra, Rafael, La monarquía, cit. (n.22), pp. 58-60, 71-73.

${ }^{67}$ La fórmula la tomamos de CorrêA DE OliveIra, Plinio, Justicia y Sacralidad en la Edad Media (Buenos Aires, SADTFP, 1973, p.28. 
libre y dotada de propia personalidad y carácter. Dichas instituciones, se entiende, crecen con una estructura natural y autónoma, y salvo la militar, independientes a los dictados del poder propiamente político ${ }^{68}$.

Más allá de la manera en que se formulen estos impulsos vitales, lo importante es comprender que la sociabilidad natural solicita la realización en comunidad de un cierto número de tendencias específicas, que abarcan todas las dimensiones del hombre, no solo el estrato -por lo demás inexistente- de la razón pura. Solo a partir del reconocimiento de esta realidad es que puede existir el "Reino". Si no se le respeta, si no se le presta atención, se edifican las condiciones para el "exilio".

Pero el "Reino" no solo se funda en bases naturales, también en bases históricas, fácticas o existenciales. Estas bases de sociabilidad dependen de mil variables: geográficas, climáticas, situacionales, voluntarias, etc. y han marcado durante siglos el derecho de los cuerpos asociativos de gobernarse a sí mismos, según las normas de su propia identidad y personalidad, como lo hicieron las agrupaciones rurales, ciudades, regiones y países, en el sentido pre-moderno de los términos. La Ilustración las descalificó en su día como "irracionales", pero lo cierto es que el poder político está llamado a "conocerlas" y no a "crearlas", como sostuvo la teoría positivista de que solo el Estado existe por derecho propio y las demás instituciones por su concesión o tolerancia ${ }^{69}$.

El "Estado racional" no reconoce ni lo natural ni lo histórico. Por oposición, el "Reino" surge del desenvolvimiento de la sociabilidad histórica y natural, excluyendo por definición la estructura superior estatal que el racionalismo impone al hombre concreto, subsumiéndolo.

La sociabilidad se condensa en tres dimensiones que constituyen las bases histórico-naturales del "Reino": el sociedalismo, el institucionalismo y la tradición. Existe una cuarta base -el vínculo religioso- que trataremos separadamente por su peculiar naturaleza y expresión.

1. El sociedalismo equivale a lo que Vázquez de Mella, denomina "soberanía social", el extenso y variado ámbito de asociaciones naturales e históricas, que el poder estatal no puede definir o intervenir a su arbitrio, porque expresa aquella realidad previa sobre la que se sostiene vitalmente el orden político. Una realidad jerarquizada de sociedades menores y mayores, autónomamente estructuradas de acuerdo con sus propias finalidades y condiciones históricas, que no necesitan del poder político para existir y desenvolverse, aunque sí para coordinarse respecto del bien común. Lo "político" no es la estructura que verticalmente se impone desde el

${ }^{68}$ Gambra, Rafael, La monarquía, cit. (n.22), pp. 107-113.

${ }^{69}$ Gambra, Rafael, La monarquía, cit. (n.22), p.110. 
poder, sino el orden diferenciado sostenido y alimentado por la actividad y la libertad de los grupos humanos, que el poder rige, pero no trastoca. Se comprende cómo este imprescindible "empirismo político", según le denomina Gambra, es incompatible con el racionalismo mecanicista de los Estados modernos ${ }^{70}$.

2. Cuando las agrupaciones son estables y forman cuerpos o estamentos solidarizados entre sí nace el "institucionalismo", esencial para la pervivencia de la sociedad natural e histórica. Sin el espíritu de institución, no puede existir propiamente un "Reino", porque los más relevantes impulsos societarios tenderían a desvanecerse como agua entre las manos. El autor sigue las teorías y observaciones de Hauriou, Renard y Faribault, pero distingue entre un institucionalismo fingido -oficial, exterior, puramente jurídico-administrativo- y uno vivo, que es la obra humana que se establece sobre lo natural y permanente para completarlo. Con ello, Gambra pretende alejarse de la concepción organicista o meramente naturalista de la formación política. También de la concepción liberal, a la que considera ciega a los elementos no inmediatamente volitivos de la génesis política.

3. Si el sociedalismo cristaliza en instituciones, éstas a su vez guardan, acrecientan, adaptan y prolongan dinámicamente en el tiempo el patrimonio espiritual y material que constituye la razón de su existir. Este movimiento de conservación y enriquecimiento continuo del propio ser institucional es la tradición.

Contra el tiempo físico, mecánico o atomizado del racionalismo, Gambra opone el tiempo social de la tradición, que expresa algo "irracional" si se quiere, pero irremediable: la evolución interior, acumulada e irreversible de todo lo humano. El autor reformula la tradición en clave bergsoniana: no representa solo coexistencia y sucesión, sino esencialmente duración interior, aquella "durée réelle" por la que en el presente gravita todo el pasado condensado sintéticamente. "La tradición-sostiene- es la traslación de ese modo de duración o temporalidad a la vida psíquica de los individuos en el plano histórico social" ${ }^{\text {"1 }}$. Es continuidad acumulativa, temporalidad creadora y entrega generacional. La tradición hace "habitable", entrañable, el mundo de lo político, permitiendo la identidad entre las generaciones y el reconocimiento mutuo de gobernantes y gobernados ${ }^{72}$.

${ }^{70}$ Gambra, Rafael, La monarquia, cit. (n.22), pp. 85-86, 107-108.

${ }^{71}$ Gambra, Rafael, Tradición o mimetismo. La encrucijada politica del presente (Madrid, Instituto de Estudios Políticos, 1976), p.26.

${ }^{72}$ Gambra, Rafael, Tradición o mimetismo, cit. (n.59), pp. 27-28. Sobre el concepto de tradición, Gambra, Rafael, La monarquía, cit. (n.22), pp. 89-101; GAmBRA, Rafael, El concepto de tradición en la filosofía actual, en Arbor 9 (1945), pp. 545-573; Gambra, Rafael, El lenguaje y los mitos, cit. (n.39), pp. 57-69. 
Sobre estas tres bases naturales y político sociales (sociedalismo, institucionalismo y tradición) se posa el "Reino", que, en nuestra interpretación, no puede ni debe ser confundido con el Estado monárquico. El "Reino" en su componente estrictamente político -el poder supremo finalizado y limitado, sobre el que hablaremos- es la prolongación de un orden ascendente nacido y estructurado des de la sociabilidad. El Estado monárquico, en cambio, se impone so b re la sociedad, sea bajo la forma de monarquía absoluta (donde se inicia históricamente la tendencia centrípeta del poder moderno), sea como monarquía constitucional (que, en realidad, es el "Estado racional" con corona).

El "Reino" es propiamente una "comunidad" política, coronada con la potestad de un Rey en el que concurren determinadas características muy distantes del poder estatal.

Para comprender el aserto, hay que seguir desbrozando el significado de algunos conceptos complementarios. En primer lugar, el de "comunidad". Gambra dedica especial atención a esta cuestión. El término lo utiliza en el sentido que le da Ferdinand Tonnies a la "Gemeinschaft", por oposición a la "Gesellschaft"73. Tras la distinción laten dos formas fundamentales de acuerdo social: la fundada en los estratos más profundos del ser y los puramente voluntario-contractuales.

La "comunidad" es siempre la relación humana más radical, fundamento de las restantes formas de convivencia, como la industria o el comercio, que se mueven en el ámbito de la coexistencia práctica o funcional. Sobre el cimiento comunitario se edificaron en Europa las constituciones históricas, expresiones políticas del modo profundo de creer, sentir, reaccionar y organizarse de los pueblos.

La "comunidad" cristaliza un conjunto de convicciones sobre el significado último de la existencia, sobre todo de la existencia política, que es lo que realmente unifica a una sociedad y hace que sus miembros se reconozcan a través del vínculo compartido. Funda además el significado social de las formas jurídicas de obligatoriedad: juramentos, contratos, deberes y derechos ${ }^{74}$.

La comunidad se expresa en una verdad u "ortodoxia pública" contra

${ }^{73}$ La distinción en Gambra, Rafael, La unidad religiosa y el derrotismo católico, cit. (n.31), pp. 47-48. El autor también recoge los conceptos de Lévy-Bruhl, Davy, Malinowsky, Tylor, Perry y Frazer.

${ }^{74}$ Gambra, Rafael, Tradición o mimetismo, cit. (n.59), pp. 33-41; Gambra, Rafael, La unidad religiosa y el derrotismo católico, cit. (n.31), pp. 49-55; GAMBRA, Rafael, La idea de comunidad en José De Maistre, en Revista internacional de Sociología 49 (1955), pp. 57-85; Gambra, Rafael, Comunidad o coexistencia, en Verbo 101 (1972), pp. 51-59. 
la noción de "sociedad abierta" del liberalismo. La "ortodoxia pública" es lo que reviste a la sociedad de un significado común. Ha sido objeto de diversos análisis en la filosofía política clásica. Equivale aproximativamente a la "politeia" de los griegos, el "cosmion" de Eric Voegelin, el "régime" de Leo Strauss o la "cultura" de T.S. Eliot ${ }^{75}$.

Por designio ideológico, el racionalismo expurgó la "comunidad" de la teoría política moderna. La idea no deja de resultar absurda teniendo en cuenta el papel pre-formante que tienen incluso las manifestaciones embrionarias de comunidad, sea en materia de ambientes, hábitos, actitudes o valoraciones. Gambra se refiere especialmente a la comunidad de sangre (la relación maternal, sexual y fraternal), la comunidad local y la comunidad de espíritu ("consensus mental").

Delimitada la noción de "comunidad", hay que precisar que el autor defiende con particular empeño el rol del vínculo religioso. La religión es esencialmente comunitaria y su papel es imprescindible para producir la unión moral que precede y sostiene la aquiescencia espontánea al orden político y jurídico. De ahí que las comunidades políticas pre-revolucionarias, tuvieran todas orígenes religiosos, según la conocida sentencia de Dawson. El neutralismo laico de los Estados racionales se impone precisamente para expurgar este vínculo tan esencial. Pero sin él declina la autoridad política, aumenta la regulación externa, y progresa la disgregación o dispersión social ${ }^{76}$.

Podemos concluir, en consecuencia, con una noción más precisa del "Reino". Por oposición al "exilio", el "Reino" supone una comunidad política que se enraíza en al menos cuatro bases histórico-naturales de la sociabilidad humana: el sociedalismo, el institucionismo, la tradición y el vínculo religioso. Los hombres son libres para desarrollar en diversos sentidos estas bases comunitarias, de acuerdo con las contingencias y peculiaridades propias del tiempo y del espacio. Aparecen, de este modo, a lo largo de la historia, comunidades políticas libres, como las repúblicas, las aristocracias o las monarquías sociales y representativas, que por su tendencia selectiva expresan el poder político supremo en la figura de un rey.

75 La observación es de Ayuso, Miguel, Koinós. El pensamiento político de Rafael Gambra, cit. ( $\left.{ }^{\circ} 17\right)$, p.134. El "Reino", en todo caso, equivale propiamente a la noción clásica de ciudad, enriquecida por el acento de los vínculos comunitarios. Se deduce de Gambra, Rafael, Sociedad y re-ligación: la ciudad como habitáculo humano, en Verbo 91-92 (1971), pp. 9-22.

${ }^{76}$ Gambra, Rafael, La monarquía, cit. (n.22), pp. 121-122. 


\section{EL PODER DEL REY}

Dijimos que el "Reino" es una especie de "comunidad política". Su concreción más perfecta se realiza en el oficio del Rey, quien por constitución histórica es titular de un poder con determinadas características.

A tal régimen, Gambra le denomina "monarquía social y representativa". Esto significa que las bases naturales y sociales del "Reino" determinan ciertas notas en el poder del Rey:

1. Es un poder de origen divin o. Como toda potestad humana, lo es de un modo mediato, transmitiéndose no a través de una jerarquía delegada sino según y en la medida de sus fines. Hay que descartar, por tanto, la doctrina protestante del origen inmediatamente divino del poder político.

2. Es un poder en esencia limitado. Una potestad política suprema en su orden, pero no soberana. Está destinada a proteger y coordinar la vida social en su conjunto. Como potestad esencialmente tutelar y encausadora del dinamismo asociativo y político de la sociedad, se opone al poder configurador del Estado "racional" 77.

3. La monarquía entraña la idea de gobierno personal, aunque cohonestado con los principios aristocráticos y democráticos en amplios sectores, de acuerdo con la formulación clásica del régimen mixto. Para Gambra el antiguo régimen político-social de los reinos españoles fue su mejor realización histórica ${ }^{78}$.

4. Es un poder de alguna manera sagrad o o san to, es decir, elevado sobre el orden puramente natural de las convenciones o la técnica política de los hombres. Por ello, la figura genuina del Rey es incompatible con el régimen parlamentario liberal nacido de la teoría de la soberanía popular ${ }^{79}$.

5. Es un poder tradicional. La monarquía ha de representar el arraigo y la continuidad frente a la improvisación y la inestabilidad. Su

77 Intrínsecamente, al poder real le compete velar por la administración superior de justicia, la defensa nacional y la suplencia de aquello que la sociedad no puede realizar por sí misma. Extrínsecamente es un poder limitado por el localismo social autónomo. GAmbra, Rafael, La monarquía, cit. (n.22), pp. 86-87.

${ }^{78}$ Las "Españas" fueron "una federación de repúblicas democráticas en los municipios y aristocráticas, con aristocracia social, en las regiones, levantadas sobre la monarquía natural de la familia y dirigida por la monarquía política del Estado". Gambra, Rafael, Estudio preliminar, en Vazquez de Mella, Juan, Textos, cit. (n.9), p.33. También, Gambra, Rafael, La monarquía, cit. (n.22), pp. 191-192. La aplicación la refiere particularmente a los reinos medievales que en evolución orgánica se transforman en la monarquía católica de los Austrias, que se proyecta al reino de las Indias. La España borbónica, sin embargo, ya es contaminada con los principios de la modernidad política, aunque el autor no lo formule en estos términos.

${ }^{79}$ Gambra, Rafael, La monarquía, cit. (n.22), pp. 138-139. 
posición es antitética al régimen de opinión y a la ideocracia. Se instala en la realidad de la tradición, y encuentra el complemento institucional en la aristocracia de eficacia directiva y enraizamiento popular, y en la familia con la plenitud de sus atribuciones ${ }^{80}$. El carácter hereditario establece un continuo con estas dos instituciones.

6. Es un poder fed e ral. Gobierna en diversas regiones con vida política relativamente autónoma. El rey corona "el gobierno del país por el país"'1.

7. Es un poder representativo. El Rey ejerce su poder en un sistema histórico de regiones, instituciones y sociedades tan diversas como autónomas. El Rey "parlamenta” institucionalmente con todas las personas colectivas y personifica la unidad en la variedad ${ }^{82}$.

8. En el contexto de la $\mathrm{Cr}$ is ti a n d a d (realizada o anhelada), el vínculo espiritual de la monarquía, que trasciende todo otro ligamen, es la fe y la moral cristianas. En polémica con el protestantismo político de Radbruch y Scheler, Gambra sostiene la tesis de la "relativa significación religiosa" del derecho y del poder político. El cristianismo inspira los límites morales -de contención- del poder. Pero también tiene un influjo positivo sobre él, tanto en su origen (non est potestas nisi a Deo) como en razón de su fin (hacer posible y coadyuvar al bien y fin últimos del hombre) ${ }^{83}$.

De lo anterior se deduce -aunque Gambra no lo explícita- que la figura del Rey ha sido alterada por el discurso político moderno, imputándole una concentración de poder (en su estructura) y una capacidad de arbitrio

${ }^{80}$ Gambra, Rafael, La monarquía, cit. (n.22), pp. 143; Gambra, Rafael, El problema de las clases directoras, cit. (n.48), pp. 366-367.

${ }^{81}$ Un amplio desarrollo en Gambra, Rafael, La monarquía, cit. (n.22), pp. 162165; Gambra, Rafael, Eso que llaman Estado, cit. (n $\left.{ }^{\circ} 21\right)$, pp. 183-190; Gambra, Foralismo y nacionalismo vasco, en Verbo 128 (1974) pp. 939-947. El federalismo se opone al nacionalismo, imaginario político uniforme incoado por el Estado racional. Gambra, Rafael, La monarquía, cit. (n.22), pp. 174-176. Es tesis del autor que el federalismo en España se identifica con el sistema foral y tiene su fundamento en la “teoría de la superposición y evolución de los vínculos nacionales". GAMBRA, Rafael, La monarquía, cit. (n.22), pp. 165-171.

${ }^{82}$ Gambra, Rafael, La monarquía, cit. (n.22), pp. 184-190.

${ }^{83} \mathrm{La}$ tesis requiere una serie de precisiones que no podemos abordar aquí. El autor las trata en diversos lugares. GAMBRA, Rafael, La unidad religiosa y el derrotismo católico, cit. (n³1), pp. 11-29, 39-43, 65-66; GAMBRA, Rafael, La filosofía religiosa del Estado y del derecho, en Revista de Filosofía 30 (1949), pp. 433-457; GAMBra, Rafael, La monarquía, cit. (n.22), pp. 121-131; GAMBRA, Rafael, Tradición o mimetismo, cit. (n59), pp. 295-297. La Cristiandad es, para Gambra, el ideal de comunidad histórico-política. GamBra, Rafael, Tradición o mimetismo, cit. (n59), pp. 45-48. Una acerva crítica de la coexistencia neutra como norma y estructura deseable para la sociedad, en GamBRA, Rafael, La unidad religiosa y el derrotismo católico, cit. ( $\left.\mathrm{n}^{\circ} 31\right)$, pp. 89-98 y Gambra, Rafael, Tradición o mimetismo, cit. (n59), pp. 295-297. 
(en su ejercicio) que poco tiene que ver con las exigencias del "Reino". En realidad, son más bien los Estados modernos los que han realizado estas onerosas características en diversos grados.

\section{CONCLUSIONES}

1. El tradicionalismo político no se comprende sin una revisión previa de las teorías e instituciones políticas modernas que han establecido y justificado una estructura artificial que impide el desenvolvimiento de la genuina comunidad política.

Para Gambra el principio basal de dichas teorías e instituciones es el racionalismo filosófico, que puede ser definido, en su denominador común, como la pretensión de la razón humana de excluir de la realidad su carácter contingente, convirtiéndola en una entidad cerrada, auto-explicativa, necesaria, penetrable sin residuo. Este modo de concebir el orden del ser y del obrar se prolonga en el racionalismo político y en toda la gama de doctrinas políticas construidas bajo su influjo.

2. La Ilustración y el espíritu revolucionario de Rousseau proyectaron reconstruir desde cero el espacio político, descartando como "irracionales" todos aquellos elementos que no podían ser pre-determinados y dominados por la razón pura, por ser realidades concretas, personales, fácticas, existenciales o históricas.

3. La Revolución Francesa puso en obra el racionalismo político,proyectando sus instituciones hasta los días de hoy: el poder constituyente y su capacidad demiúrgica; el pacto social descarnado y artificioso; el Estado "racional" y la destrucción de las autonomías sociales; el carrusel de constituciones escritas promulgadas sin la debida atención a la constitución histórica; la soberanía política y el desarrollo del poder total.

4. En su conjunto, el racionalismo político representa la gran revolución contra la sociabilidad humana, que con el paradigma del constitucionalismo y la democracia liberal (o socialista, según el caso) finge ignorar su propia crisis, llevando a la sociedad a esa situación de desarraigo e inestabilidad políticas que el autor denomina "exilio".

5. Particularmente el liberalismo es responsable del proceso histórico de desvinculación de las sociedades europeas e hispanoamericanas, característica esencial del "exilio". Al Estado liberal se le imputa el haber desatado la racionalización política, con la subsecuente desaparición del mundo extenso y cordial de las instituciones históricas y la emergencia de una serie de fenómenos socio-políticos y jurídicos puramente formales, a las que nos hemos acostumbrado, pero que son patológicos: la reglamentación exterior y uniforme de la sociedad, la ciudadana abstracta, el desarraigo en 
las relaciones jurídicas laborales y económicas, la mutación del Estado, el Derecho y Libertad en realidades absolutas y descarnadas.

6. Si los sistemas racionalistas (como el Estado liberal) son imposiciones de ideólogos y aprioristas, la "comunidad política" es efecto natural de la sociedad. Su punto de partida es la naturaleza humana, donde están "pre-formadas" las asociaciones fundamentales, en cuanto han de canalizar las tendencias específicas de la persona humana. Ese punto de partida es un dato previo para la razón, y enraíza en estratos ónticos diversos, no puramente racionales. De ahí la complejidad y adaptabilidad de la realidad asociativa, que el poder político ha de reconocer y no dominar.

7. El "Reino" se forma autónoma y vitalmente a través de una jerarquía variable de asociaciones naturales e históricas, mayores y menores. El Estado moderno que absorbe la sociedad o la configura uniformemente según principios abstractos y a-históricos, como el pacto social, la libertad o la igualdad, impiden el normal desarrollo de la naturaleza social y política del hombre, y de su fruto, la comunidad política, que es el supuesto del "Reino".

8. En este sentido, la comunidad política se funda en tres bases naturales e históricas: el sociedalismo, que expresa la autonomía y el autogobierno de los cuerpos asociativos que conforman la sociedad; el institucionalismo, por el cual dichos cuerpos arraigan y permanecen en el tiempo, enmarcando las libertades y derechos; y la tradición, mediante la cual se transmite, acrece y adapta el patrimonio moral y material de las instituciones vivas. El tiempo real y social no es el tiempo de los esquemas fríos del racionalismo individualista, sino el tiempo personal de la tradición.

9. Hay una cuarta base: el vínculo religioso, que permite la más intensa forma de unión moral entre los hombres y justifica el sentido último de la existencia política.

10. Las cuatro bases precedentes, en recíproca confluencia, dan origen a la "comunidad" natural e histórica, fundamento del orden político. Sin esta comunidad política no puede existir orden, solo sistemas abstrusos impuestos desde el exterior. La noción de "Reino" se asienta en esta noción de comunidad política.

11. La concreción más perfecta del Reino se realiza en la monarquía social y representativa, una comunidad política donde el oficio de gobernar es entregado a un Rey, quien por derecho natural y constitución histórica, es titular de un poder de origen mediatamente divino, en esencia limitado, personal, sagrado, hereditario, federal y representa tivo. En el contexto de la Cristiandad histórica o anhelada, es además un poder cristiano. El poder del Rey no se compara con el poder del 
Estado soberano. Se trata de una potestad tutelar, de coordinación y de suplencia, que parlamenta con la sociedad sin intervenirla.

\section{BIBLIOGRAFÍA}

Alvear, Julio, Francisco Suárez y los límites del poder político, en Sánchez, Pablo (Dir.), Historia del análisis político (Madrid, Tecnos, 2011), pp. 267-277.

Artigas, José, La huella de García Morente, en AA.VV., Comunidad humana y tradición política. Liber Amicorum de Rafael Gambra (Actas, Madrid, 1998), pp. 161-181. Ayuso, Miguel, La filosofía jurídica y política de Francisco Elías de Tejada (Madrid, Fundación Elías de Tejada, 1994).

Ayuso, Miguel, Rafael Gambra en el pensamiento tradicional, en AA.VV., Comunidad humana y tradición politica. Liber Amicorum de Rafael Gambra (Actas, Madrid, 1998), pp. 19-33.

Ayuso, Miguel, Koinós. El pensamiento político de Rafael Gambra (Madrid, Speiro, 1998).

Aparisi y Guijarro, Antonio, El Rey de España (Madrid, Tip. Ramón Ramierz, 1869).

BELL, Dora, L'idéal éthique de la royauté en France au moyen âge: d'après quelques moralistes de ce temps (París, Droz, 1962).

Born, Lester Kruge, The perfect Prince: a study in $13^{\text {th }}$ and $14^{\text {th }}$ century ideals, en Speculum III (1928), pp. 470-504.

Boureau, Alain et INGERflom, Claudio Sergio, La royauté sacrée dans le monde chrétien (París, Ecole des hautes études en sciences sociales, 1992).

Bravo Lira, Bernardino, El Estado de Derecho en la historia de Chile (Santiago, Ediciones Universidad Católica de Chile, 1996).

Castellano, Danilo, La politica anti-moderna de Rafael Gambra, en AA.VV., Comunidad humana y tradición politica. Liber Amicorum de Rafael Gambra (Actas, Madrid, 1998), pp55-67.

Compagnon, Antoine, Los antimodernos (Traduc. de Manuel Arranz, Barcelona, Acantilado, 2007).

CorrêA de Oliveira, Plinio, Justicia y Sacralidad en la Edad Media (Buenos Aires, SADTFP, 1973)

Carlos VII, Carta Manifiesto al Infante don Alfonso de Borbón y Austria-Este, en FERRER, Melchor, Escritos Politicos de Carlos VII (Madrid, Editora Nacional, 1957), pp. 38-43.

DEL Burgo, Jaime, Ideario (Madrid, CTC, 1979, 6a ed.)

D’Agostino, Francesco, Filosofia del diritto (Torino, Giappichelli, 1993).

Dawson, Christopher, Los dioses de la Revolución (Madrid, Encuentro, 2015).

DICKINSON, John, The medieval conception of kingship and some of its limitations, as developed in the Policraticus of John of Salisbury, en Speculum (1926), pp. 308-337.

Donoso Cortés, Juan, Obras (Madrid, Imprenta de Tejado, 1855), Tomo V.

D’Ors, Alvaro, Ensayos de Teoría Política (Pamplona, Eunsa, 1979).

D'Ors, Alvaro, Escritos varios sobre derecho en crisis (Roma-Madrid, CSIC, 1973).

D'Ors, Alvaro, Nueva Introducción al estudio del derecho (Madrid, Civitas, 1999).

D'Ors, Álvaro, Rafael Gambra y Europa, en AA.VV., Comunidad humana y tradición politica. Liber Amicorum de Rafael Gambra (Actas, Madrid, 1998), pp. 69-77. 
Dugan, Anne K. (Comp.), Kings and Kingship in Medieval Europe (London, King's College London Mediaeval Studies, 1993).

Elías de Tejada, Francisco, Las Españas. Formación histórica. Tradiciones regionales (Madrid, Ambos Mundos, 1948).

Elías de Tejada, Francisco, Historia de la literatura politica en las Españas (Madrid, Real Academia de Ciencias Morales y Políticas, 1991), Vol. II y Vol. III.

Elías DE TEJADA, Francisco, La monarquía tradicional (Madrid, Rialp, 1954).

Elías de Tejada, Francisco, Poder y autoridad: concepción tradicional cristiana, en AA.VV., Poder y Libertad (Madrid, Speiro, 1970), pp. 157-175.

Forment, Eudaldo, Gambra intérprete de la crisis existencialista, en AA.VV., Comunidad humana y tradición politica. Liber Amicorum de Rafael Gambra (Actas, Madrid, 1998), pp. 109-129.

FurEt, Francois, La Revolución Francesa en debate (Buenos Aires, Siglo XXI, 2016). Galvao de Souza, José Pedro, La representación politica (Madrid, Marcial Pons, 2011). Gambra, Rafael, Historia sencilla de la filosofia (Madrid, Rialp, 1999, 24 ed.).

Gambra, Rafael, La moral del existencialismo, en Revista de Filosofía 42 (1952).

Gambra, Rafael, Eso que llaman Estado (Madrid, Montejurra, 1958).

Gambra, Rafael, La moral existencialista y los cauces de su posible superación, en Anales de la Real Academia de Ciencias Morales y Políticas 2 (1955) pp. 246-256.

GAMBRA, Rafael, La monarquía social y representativa en el pensamiento tradicional (Madrid, Rialp, 1954).

Gambra, Rafael, Historia sencilla de la filosofía (Madrid, Rialp, 1999, 24 edición)

Gambra, Rafael, Prólogo a Jouvenel, Bertrand de, El Poder (Madrid, Editora Nacional, 1956), pp. 7-14.

GAMBRA, Rafael, La unidad religiosa y el derrotismo católico. Estudio sobre el principio religioso de las sociedades históricas y en particular sobre el catolicismo en la nacionalidad española (Sevilla, Editorial Católica, 1965).

GAMBRA, Rafael, La aceleración de la historia y el progresismo católico, en Verbo 33 (Madrid), 1965, pp. 171-185.

Gambra, Rafael, El mito del progreso, en Verbo 73 (Madrid), 1969, pp. 159-177.

Gambra, Rafael, El Movimiento de la historia, en Verbo 235 (Madrid), 1985, pp. 583-593.

Gambra, Rafael, El lenguaje y los mitos (Madrid, Speiro, 1983)

Gambra, Rafael, La última posición de Camus, en Arbor 98 (1954), pp. 135-142.

Gambra, Rafael, Rebelión y Revolución en la obra de Camus, en Nuestro Tiempo 69 (1960), pp. 120-130.

Gambra, Rafael, El exilio y el reino, en Verbo 231-232 (1984), pp. 73-94.

Gambra, Rafael, La ciudad humana de Antoine de Saint Exupéry, en Atlántida 5 (1963), pp. 503-524.

GAMBra, Rafael, Sociedad y re-ligación: la ciudad como habitáculo humano, en Verbo 91-92 (1971), pp. 9-22.

Gambra, Rafael, Libertad en la sociedad cristiana y en la sociedad de masas, en Verbo 84 (1970), pp. 283-300.

GamBRA, Rafael, Las raices eternas de la libertad, en Verbo 261-262 (1987), pp. 179-190.

Gambra, Rafael, El mal social, en Revista Internacional de Sociología 46 (1954), pp. 219-228. 
Gambra, Rafael, El García Morente que yo conoci (aquella extraordinaria irrupción de la gracia), en Nuestro Tiempo 32 (1957), pp. 131-172.

Gambra, Rafael, El problema de las clases directoras en la sociedad contemporánea, en Revista Internacional de Sociología 18 (Madrid), 1947, pp. 364-367.

Gambra, Rafael, El silencio de Dios (Madrid, Editorial Prensa Española, 1968), pp. 176-189.

Gambra, Rafael, Tradición o mimetismo. La encrucijada politica del presente (Madrid, Instituto de Estudios Políticos, 1976).

Gambra, Rafael, El concepto de tradición en la filosofía actual, en Arbor 9 (1945), pp. 545-573.

Gambra, Rafael, La idea de comunidad en José De Maistre, en Revista internacional de Sociología 49 (1955), pp. 57-85.

Gambra, Rafael, Comunidad o coexistencia, en Verbo 101 (1972), pp. 51-59.

Gambra, Rafael, Foralismo y nacionalismo vasco, en Verbo 128 (1974) pp. 939-947.

Gambra, Rafael, La filosofía religiosa del Estado y del derecho, en Revista de Filosofía 30 (1949), pp. 433-457.

García Pelayo, Manuel, El Reino de Dios, Arquetipo Político (Madrid, Revista de Occidente, 1959)

Goulemoт, Jean-Marie, Adieu les philosophes: que reste-t-il des Lumières? (París, Seuil, 2001).

Grossi, Paolo, Mitología jurídica de la Modernidad (Madrid, Trotta, 2003).

GuZmán Brito, Alejandro, El derecho privado constitucional de Chile (Valparaíso, Ediciones Universitarias de Valparaíso de la Universidad Católica de Valparaíso, 2001).

Heidegger, Martín, Carta sobre el humanismo (trad. A. Wagner de Reyna, Santiago, Universidad de Chile, 1953).

Jellinek, Georg, Teoría General del Estado, (traducc. de Fernando de los Ríos, Granada, Comares, 2000).

Jouvenel, Bertrand de, Los orígenes del Estado moderno. Historia de las ideas políticas del siglo XIX, (Toledo, Emesa, 1977).

Jouvenel, Bertrand de, El Poder. Historia natural de su crecimiento (Madrid, Unión Editorial, 1998).

Kaufmann, Arthur, La filosofia del derecho en la posmodernidad (Bogotá, Temis, 1992).

Le Goff, Jacques et Schmitт, Jean-Claude (comps.), Dictionnaire raisonné de l'Occident medieval (París, Fayard, 1999).

Le Goff, Jacques, Saint Louis (Notre Dame, University Notre Dame Press, 2009).

Maravall, José Antonio, El concepto de reino y los "Reinos de España" en la Edad Media, en Revista de Estudios Políticos 73 (1954), pp. 81-144.

Mariana, Juan de, Del Rey y de la institución de la dignidad real (traducción de E. Barriobero, Buenos Aires, Partenon, 1954).

Millán Puelles, Antonio, Compromiso y razón. En torno a la figura intelectual de Rafael Gambra, en AA.VV., Comunidad humana y tradición politica. Liber Amicorum de Rafael Gambra (Actas, Madrid, 1998), pp35-45.

Montejano, Bernardino, Saint-Exupéry visto por Rafael Gambra, en AA.VV., Comunidad humana y tradición politica. Liber Amicorum de Rafael Gambra (Actas, Madrid, 1998), pp. 131-145.

Negro, Dalmacio, La tradición liberal y el Estado (Madrid, Unión Editorial, 1995).

NieTzsche, Friedrich, Asi habló Zaratustra, II, 11, Del nuevo idolo. 
OAKeshotT, Michael, Rationalism in Politics, (London, Methuen, 1962).

Oakeshott, Michael, Lecciones de Historia del Pensamiento Político (traducción de Francisco Javier López, Madrid, Unión Editorial, 2012).

Ortiz, Marco, El concepto de rey, reino y territorio en las Siete Partidas, en Revista del Posgrado en Filosofia de la Universidad de los Andes, 23 (2012).

Polo, Fernando, ¿Quién es el Rey? La actual sucesión dinástica en la Monarquía Española (Sevilla, Editorial tradicionalista, 1968).

Puy, Francisco, Teoría Tópica del Derecho Natural (Santiago, Universidad Santo Tomás, 2004).

Quevedo, Francisco de, Política de Dios, Gobierno de Cristo, en El Mismo, Escritos Políticos (Madrid, Editora nacional, 1956).

Rodríguez, Victorino, Gambra en la polémica del orteguismo católico, en AA.VV., Comunidad humana y tradición política. Liber Amicorum de Rafael Gambra (Actas, Madrid, 1998), pp. 147-159.

Santa Cruz, Manuel, Rafael Gambra y el carlismo, en AA.VV., Comunidad humana y tradición política. Liber Amicorum de Rafael Gambra (Actas, Madrid, 1998), pp. 79-87.

Schmitт, Carl, Estudios políticos (Traducción de Francisco Javier Conde, Madrid, Doncel, 1975).

Senellart, Michel, Les arts de gouverner. Du "Regimen" medieval au concept de gouvernement (Paris, Seuil, 1995).

Serrano, José Miguel, Gambra y el reencuentro del tiempo, en AA.VV., Comunidad humana y tradición politica. Liber Amicorum de Rafael Gambra (Actas, Madrid, 1998), pp. 183-193.

Spaemann, Robert, Lo natural y lo racional (Santiago, IES, 2009).

SuÁrez, Francisco, Defensio Fidei. III Principatus politicus (Madrid, CSIC, 1965).

SuÁreZ, Francisco, Defensio Fidei. IV Iuramento Fidelitatis Regis Angliae (Madrid, CSIC, 1978).

Tomás de Aquino, De regno ad regem Cypri (Toronto, The Pontifical Institute of Mediaeval Studies, 1949).

Tulard, Jean (Dir.), La Contre-Révolution. Origines, historie, postérité (París, Perrin, 2013).

Vallet de Goytisolo, Juan, La obra de Rafael Gambra desde la Filosofía del Derecho, en AA.VV., Comunidad humana y tradición politica. Liber Amicorum de Rafael Gambra (Actas, Madrid, 1998), pp. 93-107.

VAllet de Goytisolo, Juan, Las diversas clases de pactismos históricos. Su puesta en relación con el concepto bodiniano de soberanía, en Anales de la Fundación Elías de Tejada 9 (2003), pp. 15-33.

Vazquez Mella, Juan, Textos de doctrina política (Estudio preliminar, selección y notas de Rafael Gambra, Madrid, Publicaciones Españolas, 1953).

VÁzquez de Mella, Juan, Obras Completas (Madrid, Junta de Homenaje a Mella, 1932), tomo XI.

VILley, Michel, La formation de la penseé juridique moderne (Paris, Montchrétien, 1975, Nouvelle édition corrigée)

VITORIA, Francisco, Relecciones Teológicas. El Estado y la Iglesia (Madrid, Publicaciones Españolas, 1960).

Volkoff, Vladimir, Du Roi (Paris, Julliard / L’Âge d'Homme, 1990). 
Wilhelmsen, Alexandra, El Manifiesto de los Persas: una alternativa al liberalismo español, en Revista de Estudios Políticos 12 (1979) pp. 141-172.

Wilhelmsem, Frederick D., La filosofía politica de Alvaro D'Ors, en Glossae: Revista de Historia del Derecho Europeo 4 (1992), pp. 152-189.

Voegelin, Eric, Hitler et les allemands (París, Seuil, 2003).

Zamora, Patricio, Reyes y Virreyes de la monarquia hispana a la luz de las significaciones políticas del siglo XVII y de la historiografia, en Revista de Humanidades 25 (2012), pp. 191-208. 